ECONOMICS

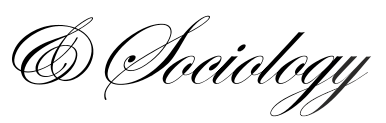

Adnan, G., \& Amri, K. (2021). Do gender empowerment and democracy reduce poverty rate? A cross-provinces evidence from western Indonesia. Economics and Sociology, 14(3), 54-71. doi:10.14254/2071-789X.2020/14-3/3

\title{
DO GENDER EMPOWERMENT AND DEMOCRACY REDUCE POVERTY RATE? A CROSS-PROVINCES EVIDENCE FROM WESTERN INDONESIA
}

\section{Gunawan Adnan \\ Universitas Islam Negeri (UIN) \\ Ar-raniry, Banda Aceh, Indonesia \\ E-mail:gunawanadnan@ar- \\ raniry.ac.id \\ ORCID 0000-0002-5568-0993 \\ Khairul Amri \\ Universitas Islam Negeri (UIN) \\ Ar-raniry, Banda Aceh, Indonesia \\ E-mail:khairul.amri@ar- \\ raniry.ac.id \\ ORCID 0000-0001-6334-7245}

Received: April, 2021

1st Revision: May, 2021

Accepted: June, 2021

DOI: $10.14254 / 2071-$

789X.2021/14-3/3

\begin{abstract}
Our study aims to explore the effect of gender empowerment and democracy on the poverty rate in western Indonesia. The data operationalized is a crosssectional data set of 8 provinces for the period of 20072018. The dynamic model of the econometric analysis was applied to analyze functional and causal relations between the three variables. Our findings discovered that there is a long-run equilibrium relationship between the poverty rate, gender empowerment, and democracy. In the long-run, both the poverty rate and democracy positively related to gender empowerment. In the short-run, the relations are negative and significant. At the 2-period horizon, gender empowerment has a negative and significant effect on poverty, but democracy has a non-significant effect on the poverty rate. The result of the Granger causality test indicates that there is a bidirectional causality between gender empowerment and democracy. Besides, unidirectional causality exists from gender empowerment and democracy to poverty rates. This finding implies that the effort of the Indonesian government to alleviate the poverty rate should consider policy intervention related to increasing gender empowerment and improving the quality of democracy. The government should encourage women's role in the economic, social, and political field. Besides, the government has to increase the democracy index by improving civil rights in economics and politics.
\end{abstract}

Keywords: poverty rates, gender empowerment, democracy, panel vector error correction model, granger causality test
JEL Classification: I32, I38, A14, J16

\section{Introduction}

Poverty has long been a social phenomenon that is commonly faced by many countries in the world, notably in developing countries (Jones \& Chant, 2009; Cho \& Kim, 2017). Therefore, efforts to eradicate poverty have become a joint commitment for countries in the world. The Millennium Development Goals (MDGs) declared at the Millennium Summit by 189 member states of the United Nations (UN) in New York in September 2000 put poverty alleviation at the top of the agenda (Liu et al., 2015). Then, the Sustainable Development Goals (SDGs) adopted by all United Nations Member States in 2015 also made poverty 
alleviation a top issue. One of the first core goals of SDGs is to alleviate extreme poverty for all people in the world by 2030 (de Jong \& Vijge, 2021).

The determinants of poverty have become an attractive issue for researchers in economics and public policy. Several studies have shown that a higher poverty rate indicates a lower welfare of the community, and these conditions aggravate various aspects of life such as social, cultural, etc. (Amri, 2019). Therefore, efforts to reduce poverty are part of the government development strategic plan (Tyer-Viola \& Cesario, 2010). In general, economic development programs in developing countries consider poverty the main issue to be alleviated (Donou-Adonsou \& Sylwester, 2016; Fosu, 2017).

In the context of the Indonesian economy, the government's concern for the importance of poverty reduction is concretely realized through poverty alleviation programs (Alisjahbana \& Pitriyan, 2016; Nazamuddin \& Amri, 2020). The program is not only a part of economic development planning at the national level, but it is also followed up by local government development programs. The allotment of local budgets to finance the construction of physical infrastructure is useful to reduce the poverty rate. However, the majority of the provinces in Indonesia are still suffering from a relatively high poverty rate. For instance, for the case of western Indonesia, although the quality of physical infrastructure in the region is better compared to eastern Indonesia, several provinces are still faced with high poverty rates. In the three regions Aceh province, Bengkulu, and South Sumatra province, for example, until March 2019, the poverty rates were $15.32 \%, 15.23 \%$, and $12.71 \%$, respectively, higher than the national poverty rate of $9.41 \%$ (Indonesian Bureau of Statistics, 2019). Instead of the Lampung province, which is a geographically closer to Jakarta, "the growth center of the Indonesian economy" also experienced a relatively high poverty rate of $12.62 \%$.

As a new democratic country, Indonesia's process of economic development to improve community welfare and eradicate the poverty rate as ,the main issue" is carried out based on democratic values and principles. The state guarantees the freedom of citizens to determine the best alternatives in all aspects of life, particularly in terms of economic activity. So far, the quality of democracy in the provinces of Indonesia has been relatively different from one another. This thing is indicated by the democratic index of the respective province. In the case of western Indonesia, up to 2018, the highest-democracy indexed province was South Sumatra (78.90), followed by Jambi (75.60) and Riau (70.20). On the contrary, the lowest-democracy indexed province was North Sumatra (69.40).

Along with persistent democracy quality improvement, the local government defines gender empowerment as the main priority. Gender empowerment reflects the active participation of women in the political and economic fields (Schuler, 2006; Klasen \& Schuler, 2009). The participation is shown through women's representation in parliament, their role in the economic field manifested in work participation, and their access to economic resources (Alfana, 2015). The achievements of the gender empowerment program in the respective province of western Indonesia are relatively different from one another. These indications are shown by the gender empowerment index. For 2018, the highest-gender empowerment index province is Riau (75.73), followed by South Sumatra (74.73), and North Sumatra (71.29). On the contrary, the lowest-gender empowerment index province is Lampung (63.82).

\section{Literature review}

Studies on the relationship between gender empowerment and democracy and poverty have been the highlight for many previous researchers (Rai, 1994; Beer, 2009). But the results of their research have not reached the fixed conclusion. The research findings of Wyndow \& Mattes (2013) using panel data set 97 countries, for instance, found that gender empowerment 
is very closely related positively to the development of democracy. In line with the findings, the results of Balaev's (2014) study also found that gender empowerment has the most prominent effects on democracy. Previously, empirical research conducted by Bayanpourtehrani \& Sylwester (2012) points out somewhat different results. They revealed that gender empowerment, especially in economic aspects, was lower in democratic countries.

In contrast to the researchers above, the findings of Rizzo et al. (2007) for the case of Arab countries provided a paradoxical conclusion. For the case of non-Muslim societies, gender empowerment positively related to democracy. The opposite result occurs for the Muslim communities is that gender empowerment had an inversed relationship with gender empowerment. Other findings on the nature of the relationship between these two variables as evident by Mervis et al. (2013) that there is no relationship between democracy and gender empowerment.

Previous studies related to the relationship between gender empowerment and poverty rate also still provide confusing results. Research conducted by Sudo (2017) found that gender empowerment negatively impacts on the poverty rate. The reason underlying the negative impacts is that increasing gender equality, particularly in the work field, lead to increase women's income, in turn, they contribute to relieving the household's economic burden (Shin, 2010). In contrast, the study of Altuzarra et al. (2019) discovered paradoxical conclusions. They found out that the relationship between gender empowerment and increasing welfare is a U-shaped inverted relationship. Thus, there are no fixed results in terms of the relationship between the two variables.

The results of previous studies on the relations between democracy and poverty rate still had been an open question. Democracy reduces poverty and improves income distribution (Knutsen, 2015). In contrast to Knutsen, the finding of Qureshi \& Ahmed's (2012) study found that there is a positive relationship between democracy and poverty rate. The poverty rate increases in democracy due to the individuals living in democratic conditions are commonly finding better choices alternatives to meet basic needs such as food, health, and housing (Aguilar, 2016). As a result, economic inequality increases that in turn, increases poverty in a community. In line with the Qureshi \& Ahmed's findings, an empirical study conducted by Chisadza \& Bittencourt's (2018) for the case of African countries also found a similar result that democracy is positively related to income inequality and poverty rate.

As explained earlier, improving the quality of democracy and gender empowerment is an inseparable part of the development process in Indonesia. However, so far, the study on the effect of these two social variables on poverty rates has not been carried out by researchers, especially for the case of western Indonesia. In contrast to previous studies, our study not just investigates the significant effect of the variables but also determine the short-run and longrun relationships between variables. Also, the direction of causality between variables more details checked one another. So, the findings of our study allow us to determine which one of the three variables firstly acts as a predictor variable for the other two variables. In turn, our findings can be useful as strategic information for local governments in Western Indonesia in evaluating the effectiveness of gender empowerment and improving the quality of democracy to reduce the poverty rate.

Systematically, we arrange the research paper into four sections. The second section is research methods that describe data operationalized, data sources, and a dynamic econometric model that applied to investigate the relationship between variables. Then, the third section is the result and discussion. The part describes the results of the descriptive statistics of each variable, the panel unit root test, the panel cointegration test, the long-run and short-run relationships, and the result of the causality relationship between variables. Lastly, the fourth section highlights conclusions and recommendations as well as research implications for future study. 


\section{Methodological approach}

Data operationalized in the study is a panel data set of eight from ten provinces from western Indonesia from 2007 to 2018. Two subnational do not have complete data related to the variables studied. Therefore, the determination of the eight provinces in this study due to the reasons for the availability of data. The data sourced from statistical reports published by the Indonesian Central Bureau of Statistics. Poverty is proxied by the annual poverty rate, which is the poor to total population ratio expressed in percents. Then, gender empowerment is proxied by the gender empowerment index. The index reflects the active role of women in the economic and political fields. The higher the gender empowerment index, the higher the role of women in the two social areas. The use of the index as a benchmark of gender empowerment refers to the previous empirical study (Klasen \& Schuler, 2009; Raj, 2017). Lastly, the measurement of democracy utilizes the democracy index. In summarized, the results of descriptive statistics of the three variables, as shown in Table 1.

Table 1. The result of descriptive statistics

\begin{tabular}{lccc}
\hline & $\begin{array}{c}\text { Poverty } \\
\text { Rate }\end{array}$ & $\begin{array}{c}\text { Gender empowerment Index } \\
(\text { GEI) }\end{array}$ & $\begin{array}{c}\text { Democracy } \\
\text { Index (DI) }\end{array}$ \\
\hline Mean & \multicolumn{2}{c}{ Descriptive Statistics } & \\
\hline Median & 13.1059 & 65.5008 & 67.7685 \\
\hline Maximum & 12.9150 & 65.7000 & 68.2250 \\
\hline Minimum & 26.6500 & 75.7300 & 80.9500 \\
\hline Std. Dev. & 6.5500 & 49.2300 & 54.0200 \\
\hline Skewness & 4.7101 & 5.3095 & 5.8678 \\
\hline Kurtosis & 0.5388 & -0.7345 & -0.3573 \\
\hline Observations & 2.4124 & 4.0082 & 2.6558 \\
\hline
\end{tabular}

Source: Indonesian Central Bureau of Statistics and Authors' Computation using E-views 9.0

The stages of data processing statistically through several steps. The first step is to conduct a data stationarity test. The statistical purpose of this test is to detect whether each data has been free of unit root symptoms. Considering that the data operationalized in this study is panel data, which is a combination of cross-section data and time-series data, the stationarity test uses two methods consisting of the Levine-Lin-Chu (LLC) method and ImPesaran-Shin (IPS) method (Im, Pesaran, \& Shin, 2003). Besides being useful for testing data stationarity, the LLC method checks for heterogeneity of intercepts across members of the panel, while the IPS detects heterogeneity in intercepts and slope coefficients. Both tests were applied by Intermediate ADF and Phillips-Perron cross-section unit tests (Maddala \& Wu, 1999; Joakim, 2006; Cerrato \& Sarantis, 2007). Finally, the method used for unit root tests consists of LLC, IPS, ADF-Fisher, ADF-Choi, PP-Fisher, and PP-Choi. The use of this method to test data stationarity has also been carried out by several previous researchers (Jiang \& Liu, 2014; Murthy \& Okunade, 2018).

The second step in the data analysis is to test the cointegrating indication of the variables studied. The concept of cointegration is most relevant to determine the long-run relationship between the variables (Granger, 1969). The basic idea that underpins cointegration is conceptually simple. If the difference "between two non-stationary series" is stationarity, indicating that the two series are cointegrated. If two or more series cointegrated, it is possible to interpret the variables in these series as being in a long-run equilibrium relationship (Engle \& Granger, 1987). By contrast, the absence of cointegration statistically 
indicates that the variables have no long-run relationship. In this respect, the cointegration test refers to Pedroni's (1999) cointegration test and Kao's (1999) cointegration test.

Further, the third step, followed by the analysis model applied to investigate the relationship between variables. In this respect, the dynamic model of the econometrics i.e the panel vector error correction model (PVECM) then utilized to analyze the relationship between poverty rates, gender empowerment, and democracy. The econometric model incorporates the traditional VAR approach putting all the variables in the system as endogenous (Yasar et al., 2006; Kumar Mandal \& Madheswaran, 2010, Grossmann et al., 2014). One of the three variables can be positioned as endogenous variables alternately, and the others as exogenous. Before applying the PVECM as a data analysis approach, we firstly determine the optimal lag length by using the Akaike information criterion (AIC). Econometrically, the PVECM model applicated to examine the causality relationship between the three variables formulated as follow:

$$
\begin{aligned}
& \Delta \operatorname{Pov}_{i t}=\alpha_{0}+\sum_{j=1}^{n} \beta_{1 j} \Delta \operatorname{Pov}_{i, t-j}+\sum_{j=1}^{n} \beta_{2 j} \Delta \mathrm{GEI}_{\mathrm{i}, \mathrm{t}-\mathrm{j}}+\sum_{\mathrm{j}=1}^{\mathrm{n}} \beta_{3 \mathrm{j}} \Delta \mathrm{DI}_{\mathrm{i}, \mathrm{t}-\mathrm{j}}+\gamma \mathrm{e}_{\mathrm{i}, \mathrm{t}-1}+\mu_{\mathrm{it}} \\
& \Delta \mathrm{GEI}_{\mathrm{it}}=\alpha_{0}+\sum_{\mathrm{j}=1}^{\mathrm{n}} \beta_{1 \mathrm{j}} \Delta \operatorname{Pov}_{\mathrm{i}, \mathrm{t}-\mathrm{j}}+\sum_{\mathrm{j}=1}^{\mathrm{n}} \beta_{2 \mathrm{j}} \Delta \mathrm{GEI}_{\mathrm{i}, \mathrm{t}-\mathrm{j}}+\sum_{\mathrm{j}=1}^{\mathrm{n}} \beta_{3 \mathrm{j}} \Delta \mathrm{DI}_{\mathrm{i}, \mathrm{t}-\mathrm{j}}+\gamma \mathrm{e}_{\mathrm{t}-1}+\varepsilon_{\mathrm{it}} \\
& \Delta \mathrm{DI}_{\mathrm{it}}=\alpha_{0}+\sum_{\mathrm{j}=1}^{\mathrm{n}} \beta_{1 \mathrm{j}} \Delta \operatorname{Pov}_{\mathrm{i}, \mathrm{t}-\mathrm{j}}+\sum_{\mathrm{j}=1}^{\mathrm{n}} \beta_{2 \mathrm{j}} \Delta \mathrm{GEI}_{\mathrm{i}, \mathrm{t}-\mathrm{j}}+\sum_{\mathrm{j}=1}^{\mathrm{n}} \beta_{3 \mathrm{j}} \Delta \mathrm{DI}_{\mathrm{i}, \mathrm{t}-\mathrm{j}}+\gamma \mathrm{e}_{\mathrm{t}-1}+\epsilon_{\mathrm{it}}
\end{aligned}
$$

where $\Delta \mathrm{Pov}$ is the first difference of the poverty rate, $\Delta \mathrm{GEI}$ is the first difference of the gender empowerment index as a measurement of gender empowerment, $\Delta \mathrm{DI}$ is the first difference of democracy index as measurement of democracy, $i$ stand for the province of $i, t$ represents the period of $\mathrm{t}$, and $\mathrm{j}$ represents the optimal lag length of the dynamic model. Furthermore, $\alpha$ and $\beta$ are constants to be estimated, as well as, $\mu, \varepsilon$, and $\epsilon$ denotes a stochastic error term of the equation, respectively. The model above can avoid loss of short-run information. The short-run deviations towards long-term equilibrium directly adjusted to long-run equilibrium. Therefore, the error term allows the imbalance proportion of the next period can be corrected. The term of error correction model (ECM) is represented by the coefficient of $\gamma$ if the variables are cointegrated one another.

In order to determine the causal relations among the variables then be analyzed by the Granger causality test. The test enables the identification of the direction of the causal relations, thus in detail can be known whether gender empowerment and democracy cause poverty rate or if the poverty rate as to cause of the two variables. To find the statistical evidence in order to answers the questions, we apply a Chi-square (Wald) test to evaluate the significant influences of a certain endogenous variable toward the exogenous variable. If the result of the test provides statistical information on the reciprocal and significant effects of the two variables, then that thing explains that a bidirectional causality exists between the two variables (Hasyim et al., 2019). 


\section{Conducting research and results}

\section{The result of unit root test}

As explained earlier, the econometric methods for unit root tests utilized to test the stationary of the panel data comprise six approaches. The approaches are namely, LLC, IPS, ADF-Fisher, ADF-Choi, PP-Fisher, and PP-Choi. The statistical result of the unit root test for the respective methods such as shown in Table 2.

Table 2. The result of panel unit root test

\begin{tabular}{|c|c|c|c|c|c|c|c|c|}
\hline \multirow[b]{2}{*}{ Variables } & \multirow{2}{*}{$\begin{array}{l}\text { Test for unit } \\
\text { root in }\end{array}$} & \multirow[b]{2}{*}{$\begin{array}{l}\text { Include in test } \\
\text { equation }\end{array}$} & \multicolumn{6}{|c|}{ Test Type } \\
\hline & & & LLC & IPS & $\begin{array}{l}\text { ADF- } \\
\text { Fisher }\end{array}$ & $\begin{array}{l}\text { ADF- } \\
\text { Choi }\end{array}$ & $\begin{array}{c}\text { PP- } \\
\text { Fisher }\end{array}$ & PP-Choi \\
\hline \multirow{8}{*}{$\begin{array}{l}\text { Poverty } \\
\text { rates }\end{array}$} & \multirow{4}{*}{ Level } & \multirow[t]{2}{*}{ Individual Intercept } & {$[-4.537]$} & {$[-1.886]$} & [25.999] & [-2.198] & [77.490] & {$[-6.025]$} \\
\hline & & & $(0.000)$ & $(0.029)$ & $(0.054)$ & $(0.014)$ & $(0.000)$ & $(0.000)$ \\
\hline & & \multirow{2}{*}{$\begin{array}{c}\text { Individual Intercept } \\
\& \text { trend }\end{array}$} & {$[-2.426]$} & {$[-0.072]$} & [16.926] & {$[-0.182]$} & {$[39.823]$} & {$[-2.311]$} \\
\hline & & & $(0.008)$ & $(0.471)$ & $(0.390)$ & $(0.428)$ & $(0.000)$ & $(0.010)$ \\
\hline & \multirow{4}{*}{$1^{\text {st }}$ difference } & \multirow[t]{2}{*}{ Individual Intercept } & [-3.799] & {$[-1.675]$} & [26.929] & {$[-2.125]$} & [47.886] & {$[-4.352]$} \\
\hline & & & $(0.000)$ & $(0.047)$ & $(0.042)$ & $(0.017)$ & $(0.000)$ & $(0.000)$ \\
\hline & & \multirow{2}{*}{$\begin{array}{c}\text { Individual Intercept } \\
\& \text { trend }\end{array}$} & {$[-3.757]$} & {$[-0.112]$} & [16.839] & {$[-0.411]$} & {$[50.490]$} & {$[-4.312]$} \\
\hline & & & $(0.000)$ & $(0.456)$ & $(0.396)$ & $(0.341)$ & $(0.000)$ & $(0.000)$ \\
\hline \multirow{8}{*}{$\begin{array}{l}\text { Gender } \\
\text { Empower- } \\
\text { ment }\end{array}$} & \multirow{4}{*}{ Level } & \multirow[t]{2}{*}{ Individual Intercept } & {$[-1.283]$} & [0.099] & {$[10.821]$} & {$[0.703]$} & {$[9.195]$} & [1.608] \\
\hline & & & $(0.099)$ & $(0.729)$ & $(0.820)$ & $(0.759)$ & $(0.905)$ & $(0.946)$ \\
\hline & & \multirow{2}{*}{$\begin{array}{c}\text { Individual Intercept } \\
\& \text { trend }\end{array}$} & {$[-3.464]$} & {$[-0.874]$} & [19.604] & {$[-1.308]$} & [18.375] & {$[-0.363]$} \\
\hline & & & $(0.000)$ & $(0.191)$ & $(0.239)$ & $(0.095)$ & $(0.302)$ & $(0.358)$ \\
\hline & \multirow{4}{*}{$1^{\text {st }}$ difference } & \multirow[t]{2}{*}{ Individual Intercept } & {$[-4.115]$} & {$[-2.226]$} & [31.107] & {$[-2.760]$} & {$[73.320]$} & {$[-6.043]$} \\
\hline & & & $(0.000)$ & $(0.013)$ & $(0.013)$ & $(0.003)$ & $(0.000)$ & $(0.000)$ \\
\hline & & \multirow{2}{*}{$\begin{array}{c}\text { Individual Intercept } \\
\& \text { trend }\end{array}$} & {$[-2.734]$} & {$[-0.042]$} & [15.700] & {$[-0.413]$} & [52.314] & {$[-4.205]$} \\
\hline & & & $(0.003)$ & $(0.483)$ & $(0.474)$ & $(0.339)$ & $(0.000)$ & $(0.000)$ \\
\hline \multirow{8}{*}{ Democracy } & \multirow{4}{*}{ Level } & \multirow[t]{2}{*}{ Individual Intercept } & {$[-2.576]$} & {$[-1.000]$} & {$[20.021]$} & {$[-1.081]$} & {$[23.744]$} & {$[-1.572]$} \\
\hline & & & $(0.005)$ & $(0.157)$ & $(0.219)$ & $(0.139)$ & $(0.095)$ & $(0.058)$ \\
\hline & & \multirow{2}{*}{$\begin{array}{c}\text { Individual Intercept } \\
\& \text { trend }\end{array}$} & {$[-4.313]$} & {$[-1.185]$} & {$[23.822]$} & {$[-1.498]$} & {$[26.789]$} & {$[-1.761]$} \\
\hline & & & $(0.000)$ & $(0.118)$ & $(0.094)$ & $(0.067)$ & $(0.044)$ & $(0.039)$ \\
\hline & \multirow{4}{*}{$1^{\text {st }}$ difference } & \multirow[t]{2}{*}{ Individual Intercept } & {$[-8.602]$} & {$[-5.269]$} & [59.509] & {$[-5.229]$} & [98.056] & {$[-7.776]$} \\
\hline & & & $(0.000)$ & $(0.000)$ & $(0.000)$ & $(0.000)$ & $(0.000)$ & $(0.000)$ \\
\hline & & \multirow{2}{*}{$\begin{array}{c}\text { Individual Intercept } \\
\& \text { trend }\end{array}$} & {$[-8.618]$} & {$[-2.442]$} & [44.446] & {$[-4.023]$} & [83.161] & [-6.807] \\
\hline & & & $(0.000)$ & $(0.007)$ & $(0.000)$ & $(0.000)$ & $(0.000)$ & $(0.000)$ \\
\hline
\end{tabular}

Source: Authors' Computation using E-views 9.0

Note: Number in bracket [ ] are W-stat for IPS, $\mathrm{X}^{2}$-stat for both ADF-Fisher and PP-Fisher, and Z-stat for both ADF-Choi and PP-Choi; number in parentheses ( ) are p-value; $\mathrm{p}$-value $<0,1$ indicate significant at 90 percent level; and $\mathrm{p}$-value $<0,05$ indicate significant at 95 percent level.

Table 2 above shows that the panel unit root test of a most of the variable produce pvalue >.05 for level data. This result statistically inform indicates that the data has not achieved a stationary at level data. Because of these reasons, the panel unit root test carry out into the first difference data. This second stage test produces a $p$-value $<.05$ for all variables, for both individual intercept and intercept and trend approach. Thus, it indicates that the data of our research was stationary at the first difference. 


\section{The result of co-integration test}

Due to the three data statistically achieved stationary at the first difference, the next stage is checking cointegration symptom of the analyzed variable. The cointegration test is useful to detect whether a long-run equilibrium relationship exists between poverty rates, gender empowerment, and democracy. In this respect, we applied three approaches for the panel cointegration test, namely Pedroni's residual cointegration test, Kao's residual cointegration, and Johansen Fisher's panel cointegration test. Pedroni (1999) suggests seven statistical tests to ascertain the existence of panel cointegration. The statistical methods divided into two approaches. The first approach pertains to panel v-statistic, panel rhostatistic, panel PP-statistic, and panel ADF-statistics. The all statistical test is termed "withindimension" (Panel test). The second approach pertains to group rho-statistic, group PPstatistic, and group ADF-statistic are termed "between-dimension" (group test). The null hypothesis proposed that there is no cointegration between the three variables, while the alternative hypothesis is that all variables are cointegrated. The result of panel co-integration test as shown in Table 3.

Table 3. The Result of Pedroni's and Kao's cointegration test

\begin{tabular}{|c|c|c|c|c|c|}
\hline \multirow{13}{*}{$\begin{array}{c}\text { Test Methods } \\
\text { Pedroni's Residual- } \\
\text { Cointegration Test }\end{array}$} & & & & & \\
\hline & \multicolumn{5}{|c|}{ Panel Cointegration Statistics (Within-Dimension) } \\
\hline & \multirow{3}{*}{ Test statistics } & \multicolumn{4}{|c|}{ Deterministic trend specification } \\
\hline & & \multicolumn{2}{|c|}{ Individual intercept } & \multicolumn{2}{|c|}{$\begin{array}{l}\text { Individual intercept and } \\
\text { individual trend }\end{array}$} \\
\hline & & t-statistics & $\mathrm{p}$-value & t-statistics & $p$-value \\
\hline & Panel v-Statistic & -0.642 & 0.739 & 0.812 & 0.208 \\
\hline & Panel rho-Statistic & 1.078 & 0.859 & 1.379 & 0.916 \\
\hline & Panel PP-Statistic & -1.445 & 0.074 & -2.265 & 0.012 \\
\hline & Panel ADF-Statistic & -0.656 & 0.256 & 1.145 & 0.874 \\
\hline & \multicolumn{5}{|c|}{ Group Mean Panel Cointegration Statistics (Between-Dimension) } \\
\hline & Group rho-Statistic & 1.884 & 0.970 & 2.641 & 0.996 \\
\hline & Group PP-Statistic & -3.381 & 0.000 & -2.227 & 0.016 \\
\hline & Group ADF-Statistic & -1.625 & 0.052 & 2.443 & 0.993 \\
\hline \multirow{4}{*}{$\begin{array}{l}\text { Kao's Residual } \\
\text { Cointegration Test }\end{array}$} & Null Hypothesis & T-Statistic & P-value & & \\
\hline & No cointegration & -1.807 & $0.035^{* *}$ & & \\
\hline & Residual Variance & 0.692 & & & \\
\hline & HAC variance & 1.541 & & & \\
\hline
\end{tabular}

Source: Authors' Computation using E-views 9.0

Note: Ho: no cointegration; p-value $<0.05$ indicate the rejection of null hypothesis at $95 \%$ confidence interval.

Table 3 above shows the results of Pedroni's (1999)'s panel cointegration tests that some of the p-values are greater than 0.05 for the Panel v-Statistic, Panel rho-Statistic, Panel ADF-Statistic, and Group rho-Statistic. On the contrary, the p-values for the Panel PPStatistic, Group PP-Statistic, and Group ADF-Statistic are smaller than 0.05, respectively. The statistical result provides a piece of inconclusive information in terms of whether a long-run cointegration relationship exists among the three variables. Therefore, the test of the long-run relationship then continued by applying Kao's residual cointegration test. The statistical result shows the p-value of $0.035(<0.05)$. The statistic information makes a fix conclusion sure that the variable co-integrated one another. 
Because of three variables have a long-run equilibrium relationship, it is necessary to determine the number of cointegration equations. In this case, we employes the JohansenFisher panel cointegration test. The results of the test, as shown in table 4.

The result of Johansen-Fisher panel co-integration test above informs that is at least there is two co-integration equation. The two equations represent the existence of a long-run relationship between the variables. Hence, econometric methods of the panel-vector error correction model (PVECM) are the best methods to be applied as means of the data analysis.

Table 4. Johansen-Fisher panel cointegration test

\begin{tabular}{|c|c|c|c|c|c|}
\hline \multirow{2}{*}{$\begin{array}{c}\text { Null } \\
\text { Hypothesis }\end{array}$} & \multirow{2}{*}{$\begin{array}{l}\text { Alternative } \\
\text { Hypothesis }\end{array}$} & \multicolumn{2}{|c|}{$\begin{array}{c}\text { Fisher Stat.* } \\
\text { (from trace test) }\end{array}$} & \multicolumn{2}{|c|}{$\begin{array}{c}\text { Fisher Stat.* } \\
\text { (from max-eigen test) }\end{array}$} \\
\hline & & Trace test & P-value & Max-eigen test & P-value \\
\hline \multicolumn{6}{|c|}{ Trend assumption: Linear deterministic trend } \\
\hline $\mathrm{r}=0$ & $r \neq 0$ & 220.0 & 0.0000 & 174.7 & 0.0000 \\
\hline$r \leq 1$ & $r>1$ & 83.73 & 0.0000 & 68.18 & 0.0000 \\
\hline$r \leq 2$ & $r>2$ & 46.08 & 0.0001 & 46.08 & 0.0001 \\
\hline \multicolumn{6}{|c|}{ Trend assumption: Linear deterministic trend (restricted) } \\
\hline$r=0$ & $r \neq 0$ & 73.68 & 0.0000 & 73.68 & 0.0000 \\
\hline$r \leq 1$ & $r>1$ & 60.30 & 0.0000 & 52.05 & 0.0000 \\
\hline$r \leq 2$ & $r>2$ & 17.73 & 0.0234 & 17.73 & 0.0234 \\
\hline
\end{tabular}

Source: Authors' Computation using E-views 9.0

Note: * Probabilities are computed using asymptotic Chi-square distribution

\section{The result of the lag length criteria}

Due to the econometric model used to test the relationship between the variables is that a dynamic model, the most important is to make an optimal lag length sure. The optimal lag length is a period horizon enabling the optimal effect of a certain variable to another. For the case, the tests used to determine the optimal lag length is that based on informational criteria - the Akaike information criterion (AIC), Hannan-Quinn criterion (HQC), and Schwarz information criterion (SIC). The respective of the criteria statistically show the different optimal lag lengths for the PVECM, as shown in Table 5. The standard information criteria of the SC and HQ shows an optimal lag length of 1, respectively. Further, the AIC shows an optimal lag length of 2 . In this respect, the information criteria utilized in determining the optimal lag length refer to the Akaike information criterion.

Table 5. The result of the optimal lag length test

\begin{tabular}{ccccccc}
\hline Lag & LogL & LR & FPE & AIC & SC & HQ \\
\hline 0 & -233.3766 & NA & 27.25487 & 11.81883 & $11.94550^{*}$ & $11.86463^{*}$ \\
\hline 1 & -225.5989 & 14.00000 & 29.02984 & 11.87994 & 12.38661 & 12.06314 \\
\hline 2 & -210.8393 & $24.35322^{*}$ & $21.96073^{*}$ & $11.59197^{*}$ & 12.47863 & 11.91256 \\
\hline 3 & -202.1425 & 13.04530 & 22.78197 & 11.60712 & 12.87378 & 12.06511 \\
\hline 4 & -196.0492 & 8.225972 & 27.44522 & 11.75246 & 13.39912 & 12.34784 \\
\hline 5 & -193.3785 & 3.204741 & 40.33379 & 12.06893 & 14.09558 & 12.80170 \\
\hline 6 & -181.7353 & 12.22538 & 39.33758 & 11.93677 & 14.34342 & 12.80694 \\
\hline
\end{tabular}

Source: Authors' Computation using E-views 9.0

Note: * indicates lag order selected by the criterion; LR: sequential modified LR test statistic; (each test at $5 \%$ level); FPE: Final prediction error; AIC: Akaike information criterion; SC: Schwarz information criterion; and HQ: Hannan-Quinn information criterion. 
As shown in Table 2 earlier, the operationalized variables achieved stationarity after the first differencing. Next, the AIC (Table 5) provides statistical information that the optimal lag length of 2. Therefore, the dynamic model of PVECM utilized to analyze the functional relationship among the poverty rates, gender empowerment, and democracy then apply the lag length of 2 .

\section{The result of panel vector error correlation model}

As explained earlier, three variables have a long-run equilibrium relationship, as shown in the results of the cointegration test in table 4 earlier. Referring to the statistical information, we then apply the vector error correction model to explore the dynamic relationship between variables. This econometric model allows us to obtain statistical information regarding the long-run and short-run relationships of the three variables (Amri et al., 2019; Ikhsan et al., 2020). Besides, the econometric model also provides information in terms of the short-run causality effects of the related variables. The long-run relationship econometrically reflected in the cointegrating equation. Then, the information regarding the short-run relationships as shown at the error correction section.

The result of Johansen Fisher panel co-integration test shows that there are at least two co-integration equations related to the functional relationship between poverty, gender empowerment, and democracy. Based on the PVECM results, the two equations are as in Table 6.

Table 6. The long-run and short-run relations between the variables

\begin{tabular}{lcc}
\hline & Co-integrating Equation & Error Correction \\
\hline CointEq1 & $\Delta \mathrm{POV}=-0.888+(0.641) \Delta \mathrm{GEI}_{\mathrm{t}-1}$ & $(-0.1953)$ \\
& {$[4.569]$} & {$[-2.3296]$} \\
\hline CointEq2 & $\Delta \mathrm{DI}=0.262+(0.425) \Delta \mathrm{GEI}_{\mathrm{t}-1}$ & $(-2.1410)$ \\
& {$[1.754]$} & {$[-7.0753]$} \\
\hline
\end{tabular}

Note: estimated coefficient in ( ); t-statistics in [ ]; t-stat $>1,96$ indicates the significant at 95\% level; and tstat $<1,96$ indicates the non-significant at $95 \%$ level; $\triangle \mathrm{POV}$ is the first difference of poverty rate, $\Delta \mathrm{DI}$ is the first difference of democracy index, and $\Delta \mathrm{GEI}$ is the first difference of the gender empowerment index.

The first co-integration equation represents the long-run equilibrium relationship between the poverty rate and gender empowerment. The gender empowerment has a positive and significant relationship with poverty rates in the long-run. This thing is that statistically shown in the estimates coefficient of 0.641 ( $\mathrm{t}$-stat of 4.569). The existence of a positive relationship between gender empowerment and poverty rate indicates that the improvement of gender empowerment is in line with the increases in poverty of the community. These findings are consistent with the result of the study conducted by Balaev (2014) found out that for democratic countries, there is a long-run relationship between gender empowerment and macroeconomic variables, such as economic development and poverty rate. Empirical reasoning underlying the existence of the long-run relationship between gender empowerment and the poverty rate is that the poverty rates are faster growing than government policies to increase gender empowerment. This phenomenon is due to the changes in the poverty rate is related to several economic and non-economic factors, including the growth rates of the population. Conversely, our finding is contrary to Brady's (2006) research in several Western democracies countries, which concluded that gender empowerment indicated by higher rates of the female labor force participation had a significant effect on reducing the poverty rate. 
The research findings of Shin (2010) for the case of Korea also concluded that there was a negative relationship between gender empowerment and poverty reduction.

The error correction sections, as seen in table 6 above, represents a short-run relationship between the poverty rate and gender empowerment. The nature relationship of the two variables shows a negative sign of -0.195 ( $t$-stat of -2.329$)$. The statistical information discovers that in the short-run, the relationship between the two variables is negative and significant. If the poverty rate lied above the long-run equilibrium, then in the next period, gender empowerment will decrease. In the economic situation of which the high rate of poverty, the equality between men and women is notably in political and economic life is hardly realized. The dominance of men over these two dimensions is greater than that of women. This thing is what causes the negative and significant relationship between these two variables in the short-run.

The second cointegration equation represents a long-run relationship between democracy and gender empowerment. In the long-run, the two variables statistically related to one another, with an estimated coefficient of 0.425 (t-stat of 1.754). Although the relationship between the two variables is positive, the relations seems not significant. However, the existence of a positive relationship between the two variables explains that the development of democracy in western Indonesia is parallel to gender empowerment. As explained earlier, gender empowerment is related to the relative empowerment of women. It contains three components that are the political representation, representation in senior positions in the economy, and access to economic resources (Klasen \& Schuler, 2009). The success of gender empowerment based on three components are positively related to democracy. Democracy enables a public space welcoming for the raising quality of gender empowerment. The rights equality between women and men on various occasions has an impact on increasing their participation in democratic activities, including in decision making. Moreover, gender equality is not only an important indicator of democratic development but also reflects the implementation of democratic values in society. This finding is in favor of the empirical results of Rizzo et al. (2007) discovering, that high support for women's rights not just impacts gender equality but also encouraged democracy. Our findings also confirm the empirical result of Wyndow \& Mattes (2013) discovered that gender empowerment has a strong relationship with democratic development.

The error correction representing a short-run relationship between democracy and gender empowerment shows an estimated coefficient of -2.141 (t-stat of -7.075). It is a surprising result, in the short-run, the relationship between the two variables is negative and statistically significant. When democracy lies above the long-run equilibrium, then in the next period, gender empowerment will fall. The negative correlation between the two variables, implicitly indicates that for the case of Indonesia, in the short-run, democratic practices tend to increase the gender gap. As a new democratic country, democracy provides more space for every citizen to increase their participation in achieving a better life. Under such conditions, the increase in male dominance in all aspects of politics, social and economy is relatively faster compared to women.

\section{The Short-run effect between the variables}

The short-run effect between variables in the dynamic equation systems of PVECM provides information that the poverty rate for a certain period was negatively affected by the poverty of the previous year, with an estimated coefficient of $-0,562$ (t-stat of -4,957). The negative effect of poverty on itself indicates that the government's efforts to reduce poverty have been relatively successful. In spite of most provinces in western Indonesia still face high poverty rates, but, in general, citizens living under the poverty line are getting smaller. 
Gender empowerment also has a negative and significant effect on the poverty rate with an estimated coefficient of -0.159 at the lag of 1 , and -0.091 at the lag of 2 , respectively. This thing indicates that an increase in gender empowerment has a statistically negative impact on community income so that the poverty rate decreases. This finding is in line with the results of Duflo's (2012) study, which found that increasing equality between men and women was beneficial for development, and women's empowerment had an impact on improving people's welfare and reducing poverty. Similarly, Nadim \& Nurlukmans (2017) also provide empirical evidence that gender empowerment considered a strategic policy instrument of poverty reduction.

Table 7. The summary of panel vector error correction model

\begin{tabular}{clllllc}
\hline \multirow{2}{*}{$\begin{array}{c}\text { Exogenous } \\
\text { Variables }\end{array}$} & \multicolumn{2}{c}{$\Delta(\Delta \mathrm{POV})$} & \multicolumn{2}{c}{$\Delta(\Delta \mathrm{DI})$} & \multicolumn{3}{c}{$\Delta(\Delta \mathrm{GEI})$} \\
\cline { 2 - 7 } & $\begin{array}{c}\text { Estimated } \\
\text { Coefficient }\end{array}$ & $\mathrm{t}-$ stat & $\begin{array}{c}\text { Estimated } \\
\text { Coefficient }\end{array}$ & $\mathrm{t}$-stat & $\begin{array}{c}\text { Estimated } \\
\text { Coefficient }\end{array}$ & $\mathrm{t}$-stat \\
\hline$\Delta(\Delta \mathrm{POV}(-1))$ & -0.562 & -4.957 & -0.348 & -0.354 & -0.629 & -1.415 \\
\hline$\Delta(\Delta \mathrm{POV}(-2))$ & -0.119 & -1.113 & -1.159 & -1.250 & -0.360 & -0.858 \\
\hline$\Delta(\Delta \mathrm{GEI}(-1))$ & -0.156 & -3.467 & 0.121 & 0.308 & -0.028 & -0.161 \\
\hline$\Delta(\Delta \mathrm{GEI}(-2))$ & -0.091 & -2.553 & 0.424 & 0.309 & 0.025 & 0.177 \\
\hline$\Delta(\Delta \mathrm{DI}(-1))$ & 0.045 & 1.797 & 0.724 & 3.323 & -0.036 & -0.361 \\
\hline$\Delta(\Delta \mathrm{DI}(-2))$ & 0.043 & 2.522 & 0.177 & 1.196 & 0.018 & 0.265 \\
\hline $\mathrm{C}$ & 0.119 & 1.641 & 0.297 & 0.469 & 0.107 & 0.371 \\
\hline & $\mathrm{R}^{2}$ & $: 0.547$ & $\mathrm{R}^{2}$ & $: 0.755$ & $\mathrm{R}^{2}$ & $: 0.482$ \\
& Adj. $\mathrm{R}^{2}$ & $: 0.482$ & Adj. $\mathrm{R}^{2}$ & $: 0.719$ & Adj. $\mathrm{R}^{2}$ & $: 0.407$ \\
& F-stat & $: 8.328$ & F-stat & $: 21.209$ & F-stat & $: 6.403$ \\
& Log likehooc: -49.138 & Log likehood & $:-187.439$ & Log likehood & $:-136.663$ \\
\hline
\end{tabular}

Source: Authors' computation using E-views 9.0

As shown in Table 7 above, democracy has a positive and significant effect on the poverty rate at the 2-period horizon with an estimated coefficient of 0.043 with t-stat of 2.522 . The increase in the democratic index in a certain period significantly impacts the increase in the poverty rate for the next two periods. These findings confirm the results of a study conducted by Chisadza \& Bittencourt (2018) for the case of African countries pointed out that a negative relationship between income per capita and democracy. They argue that democracy drives income inequality in society due to the individuals living in a democracy have better choices to meet their basic needs such as food, health, housing, and education. Such condition increases competition to find better welfare, thereby increasing income inequality. In turn, income inequality encourages an increase in poverty rates (Aguilar, 2016). On the contrary, this finding contrasts with the results of Knutsen's (2015) study, which concluded that democracy reduces poverty and improves income distribution. This finding is also not in line with the results of Barro's (1997) study, which provided empirical evidence that democracy has an inline direction with people's welfare.

The effect of the poverty rate on democracy is relatively weak both at the 1 and 2period horizons. This thing indicates that the poverty rate does not cause changes in the democracy quality in western Indonesia. At the same time horizon, the effect of poverty rate on gender empowerment is also negative and insignificant. In other words, the increasing poverty rate does not significantly affect the decreases in gender equality between men and women. Even though in conditions of high poverty, men dominate more decisions related to 
all parts of life, but these conditions do not significantly impact the neglect of women's role in the community.

\section{The result of variance decomposition analysis}

To check the ability of a variable in explaining the variance of one another, we employe the variance decomposition analysis (VDA). Besides explaining the dynamic interactions between the variables (poverty rates, gender empowerment, and democracy), the analysis also statistically informs the contribution of a certain variable to the variance of another variable (Amri \& Nazamuddin, 2018; Amri, 2018). At the 4-period horizon, the variance of poverty rate explained by its forecast error variance around 82.85 percent. This indicates that the poverty rate is mostly important to explain the change of its own self. The VDA also statistically informs that democracy and the gender empowerment contributes up to 11.51 percent and 5.64 percent of the forecast error-variance of poverty rate for the same period horizon, respectively. Table 8 below represents the VDA of the three variables.

Table 8. The result of the variance decomposition

\begin{tabular}{clllcccccc}
\hline \multirow{2}{*}{ Period } & \multicolumn{3}{c}{$\begin{array}{c}\text { Variance Decomposition } \\
\text { of } \Delta \text { POV }\end{array}$} & \multicolumn{3}{c}{ Variance Decomposition } & \multicolumn{3}{c}{ Variance Decomposition } \\
& \multicolumn{1}{c}{$\Delta$ POV } & $\Delta$ DI & $\Delta$ GEI & $\Delta$ POV & $\Delta$ DI & $\Delta$ GEI & $\Delta$ POV & $\Delta$ DI & $\Delta$ GEI \\
\hline 1 & 100.000 & 0.000 & 0.000 & 6.526 & 93.475 & 0.000 & 0.175 & 2.354 & 97.471 \\
2 & 92.085 & 1.069 & 6.846 & 9.144 & 89.373 & 1.483 & 1.332 & 4.562 & 94.106 \\
3 & 92.677 & 1.031 & 6.292 & 8.257 & 87.772 & 3.971 & 1.256 & 4.405 & 94.339 \\
4 & 82.853 & 11.507 & 5.639 & 7.592 & 88.720 & 3.687 & 2.048 & 5.948 & 92.004 \\
5 & 75.267 & 11.832 & 12.901 & 13.114 & 82.032 & 4.854 & 4.714 & 5.292 & 89.994 \\
6 & 72.551 & 11.831 & 15.618 & 14.749 & 80.484 & 4.766 & 4.343 & 5.346 & 90.311 \\
7 & 70.367 & 12.195 & 17.438 & 14.494 & 78.317 & 7.189 & 4.792 & 5.203 & 90.005 \\
8 & 70.561 & 12.150 & 17.289 & 14.567 & 78.309 & 7.123 & 4.879 & 5.019 & 90.100 \\
9 & 69.261 & 11.991 & 18.748 & 14.455 & 77.453 & 8.092 & 4.973 & 4.778 & 90.247 \\
10 & 67.021 & 11.663 & 21.316 & 14.565 & 77.341 & 8.094 & 4.941 & 4.531 & 90.528 \\
\hline
\end{tabular}

Source: Authors' computation using E-views 9.0

Note: $\Delta$ Pov denotes the first difference of poverty rates; $\Delta$ DI denotes the first difference of democracy index; and $\Delta$ GEI denotes the first difference of gender empowerment index.

The variant of democracy (DI) explains around 80.48 percent of its forecast error variance at the 6-period horizon. At the same period horizon, the contribution of the poverty rate and gender empowerment on democracy are 4.77 percent and 4.34 percent, respectively. Accordingly, the two variables have a smaller amount of contribution in explaining the variant of the poverty rate.

\section{The result of Granger causality test}

Granger causality test trusted as an econometric model that can explain the direction of causality between variables. Since we operationalize the panel data set, the causality test that we apply to investigate the nature of the relationship is the panel Granger causality test. The test is an integral part of PVECM. The result of the test indicates that there is bidirectional causality exists between gender empowerment and democracy. Democracy development causes gender empowerment, and gender empowerment also causes democracy. These findings confirm the views of Inglehart et al. (2002) explicitly affirms is that support for gender equality is not just a consequence of democratization. Conversely, democracy also 
encourages gender equality in the community. The presence of causality from democracy to gender empowerment is favor of Duflo's (2012) research findings which prove, that the increasing role of women in economic and social activities is closely related to economic development. On the one side, development plays an important role (a major role in driving down inequality between men and women). On the other side, raising women's roles may benefit development. The development process will bring about women's empowerment and vice versa, empowering women will bring about changes in decision making, which in turn directly impacts the development. The result of the panel Granger causality test summarized in Table 9.

Table 9. The result of panel granger causality tests

\begin{tabular}{cccc}
\hline Endogenous & \multicolumn{3}{c}{ Exogenous Variables } \\
\cline { 2 - 4 } Variables & $\Delta$ Pov & $\Delta$ DI & $\Delta$ GEI \\
\cline { 2 - 4 }$\Delta$ Pov & - & $(3.629)$ & $(6.914)$ \\
& $(0.011)$ & {$[0.057]^{*}$} & {$[0.009]^{* * *}$} \\
\hline \multirow{2}{*}{$\Delta$ DI } & {$[0.915]$} & - & $(5.598)$ \\
& $(0.633)$ & $(4.196)$ & {$[0.018]^{* *}$} \\
\hline \multirow{2}{*}{$\Delta$ GEI } & {$[0.426]$} & {$[0.041]^{* *}$} & - \\
\hline
\end{tabular}

Source: Authors' Computation using E-views 9.0

Note: $\Delta$ is the first difference operator, the values in parentheses ( ) are chi-square, the values in bracket [ ] are p-values. *,*, and $* * *$ indicate the significant at $90 \%, 95 \%$ and $99 \%$ level, respectively.

Based on the results of the granger causality test shown in table 9 above, the direction of causality between the three variables, as shown in Figure 1.

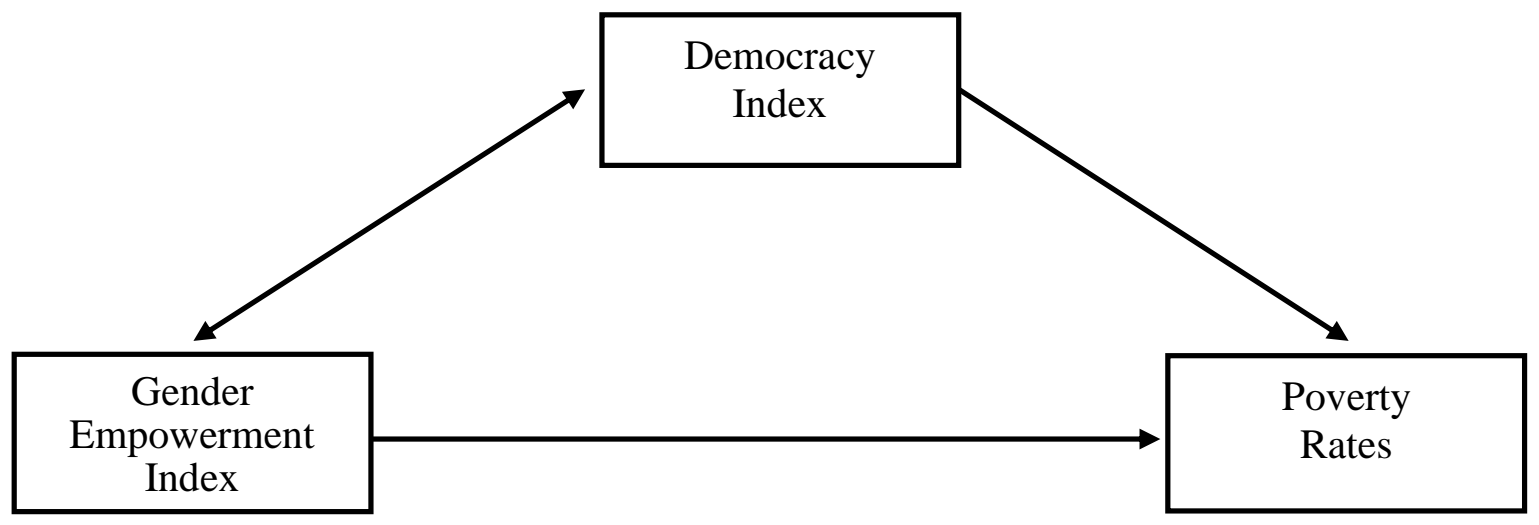

Figure 1. The direction of causality relationship between the research variables Source: own compilation

Our findings pointing out the empirical evidence on the presence of bidirectional causality between democracy and gender empowerment are also in line with the results of Tremblay's (2007) study discovering a mutual relationship between the two variables. In the case of parliamentary elections, for example, the voting system in general election is the main determinant of the proportion of women in legislatures. In contrast, in relatively wellestablished democracies, the logical explanation for the phenomenon related to the conception of gender roles. Previously, Lindberg's (2004) study also found that women's empowerment 
improved the quality of democracy. On the other hand, in democratic governments, women's participation in decision making will also increase (Oke, 2015).

One-way causality exists from gender empowerment to the poverty rate. Increased gender equality indicates that there is an improvement in the role of women in economic aspects so that they play a role in improving family welfare. This thing is what causes gender empowerment to impact poverty. This finding is consistent with the results of Brady's (2006) study using panel data from 18 countries, which also provide empirical evidence that an increase in gender empowerment contributes positively to their family income, and in turn, decreases the poverty rate in the community. Furthermore, one-way causality also occurs from democracy to poverty. This thing indicates that the development of the quality of democracy also causes changes in the poverty rate.

The result of the panel causality test in the table above shows that there is no causality from poverty to democracy and gender empowerment. This statistical information implicitly indicates that the phenomenon of poverty in western Indonesia is not a significant cause of gender empowerment. The raising of gender empowerment is not a response to the shock of the poverty experienced by the community. This finding is contrary to the results of Wietzke's (2019) research using data from developing countries point out that poverty reduction has a stronger influence on democracy.

\section{Conclusion}

Discussion on the relationship between democracy and gender empowerment and poverty has become an interesting debate among economic and social researchers. This thing is due to poverty as "an economic disease" still faced by many countries in the world, including democracies that have been giving better attention to the issue of gender empowerment. As a new democratic country in the world, Indonesia has sought to reduce poverty by making gender empowerment issues surely as an important program of efforts to improve the welfare of society. However, the majority of regions in western Indonesia still faced higher poverty rates.

The purpose of our study is to investigate the effect of gender empowerment and democracy on poverty rates in western Indonesia. Using a panel data set is that the combination of a cross-sectional data of 8 provinces and time-series data for 2007-2018, the dynamic model of econometrics utilized to analyze the functional relationship of the three variables. The econometric model comprises of Kao's co-integration test, PVECM, and granger causality test.

Our study reveals that cointegration relations exist among the three variables. In the long-run, gender empowerment positively and significantly related to poverty rates. The longrun relationship between gender empowerment and democracy is also positive but not significant. Further, in the short-run, the relationship of gender empowerment and poverty rate as well as between gender empowerment and democracy are statistically negative. Panel Granger causality test result indicates that there is bidirectional causality between gender empowerment and democracy. In other words, the two variables affect one another. Gender empowerment causes democracy, and vice versa, democracy also causes gender empowerment. Further, there is a unidirectional causality running from gender empowerment and democracy toward the poverty rate. These empirical pieces of information imply that the economic development programs related to poverty reduction need to making gender empowerment and democracy surely as a fundamental basis of policy.

Referring to the conclusions above, the local governments in western Indonesia should encourage the improvement of democracy quality and gender equality. However, the increases in the two social aspects need to consider a pearl of local wisdom in communities, 
notably for gender empowerment. In theory and supported by our research findings, gender empowerment that directly impacts poverty reduction is increasing women's opportunities in economic life. Earlier, the result of qualitative research conducted by Adnan (2017) also recommended that the development process to reduce poverty and improve the economic welfare of the community must be in line with increasing the active participation of women. Therefore, the local government in western Indonesia needs to make a strategic policyoriented to gender equality in the economic field. Besides, regarding the improvement of democracy quality, the local governments should increase the democracy index by improving civil rights in economics and politics.

\section{References}

Adnan, G. (2017). Gender mainstreaming in the context of Aceh development, Marwah: Jurnal Perempuan, Agama dan Jender, 16(2), 127-140.

Aguilar, K. M. M. (2016). The Impact of democracy on poverty levels, Academic Journal of Interdisciplinary Studies, 5(3), 491-498.

Alfana, M. A. F., Fauzan, D., Laksmiasri, W., \& Rahmaningtias, A. (2015). Dinamika pembangunan manusia berbasis gender di Indonesia (Dynamics of gender-based human development in Indonesia) Proceeding, Seminar Nasional Geografi UMS.

Alisjahbana, A. S., \& Pitriyan, P. (2016). Lessons from effective poverty alleviation in indonesia: The role of women empowerment and community participation, Working Paper in Economics and Development Studies No. 201601.

Altuzarra, A., Gálvez-Gálvez, C., \& González-Flores, A. (2019). Economic development and female labour force participation: The case of European union countries, Sustainability 11, 3-18.

Amri, K. (2018). The macroeconomic impact of regional minimum wages: A cross-province data evidence from Indonesia. Regional Science Inquiry. 10(3), 163-176.

Amri, K. (2019). Pengaruh zakat dan kesempatan kerja terhadap tingkat kemiskinan di Aceh (Effect of zakah and employment on poverty rates in Aceh), Jurnal Al-Muzara'ah, 7(2), 55-70.

Amri, K., \& Nazamuddin. (2018). Is there causality relationship between economic growth and income inequality? Panel data evidence from Indonesia, Eurasian Journal of Economics and Finance, 6(2), 8-20.

Amri, K., Nazamuddin, Masbar, R., \& Aimon, H. (2019). Is there a causality relationship between local tax revenue and regional economic growth? A panel data evidence from Indonesia, Regional Science Inquiry, 11(1), 73-84.

Balaev, M. (2014). Improving models of democracy: The example of lagged effects of economic development, education, and gender equality. Social Science Research, 46, 169-183. doi:10.1016/j.ssresearch.2014.03.004.

Barro, R. (1997) Determinants of economic growth: a cross country empirical study. MIT Press, Cambridge, MA.

Bayanpourtehrani, G., \& Sylwester, K. (2012). Democracy and female labor force participation: An empirical examination. Social Indicators Research, 112(3), 749-762. doi:10.1007/s11205-012-0080-2.

Beer, C. (2009). Democracy and gender equality. Studies in Comparative International Development, 44(3), 212-227. doi:10.1007/s12116-009-9043-2.

Brady, D. (2006). Structural theory and relative poverty in rich Western democracies, 19692000. Research in Social Stratification and Mobility, 24(2), 153-175. doi:10.1016/j.rssm.2005.02.004. 
Cerrato, M., \& Sarantis, N. (2007). A bootstrap panel unit root test under cross-sectional dependence, with an application to PPP. Computational Statistics \& Data Analysis, 51(8), 4028-4037. doi:10.1016/j.csda.2006.12.025.

Chisadza, C., \& Bittencourt, M. (2018). Economic development and democracy: The modernization hypothesis in sub-saharan, Africa. The Social Science Journal. doi:10.1016/j.soscij.2018.10.007.

Cho, S., \& Kim, T. (2017). Determinants of poverty status in Rwanda. African Development Review, 29(2), 337-349. doi:10.1111/1467-8268.12260.

de Jong, E., \& Vijge, M. J. (2021). From Millennium to Sustainable Development Goals: Evolvingdiscourses and their reflection in policy coherence for development. Earth System Governance, 7. doi: 10.1016/j.esg.2020.100087.

Donou-Adonsou, F., \& Sylwester, K. (2016). Financial development and poverty reduction in developing countries: New evidence from banks and microfinance institutions. Review of Development Finance, 6(1), 82-90. doi:10.1016/j.rdf.2016.06.002.

Duflo, E. (2012). Women empowerment and economic development, Journal of Economic Literature 50(4), 1051-1079, https://doi.org/10.1257/jel.50.4.1051.

Engle, R. F., \& Granger, C.W.J. (1987). Co-integration and error correction: Representation, estimation, and testing, Econometrica, 55(2), 251-76.

Fosu, A. K. (2017). Growth, inequality, and poverty reduction in developing countries: Recent global evidence. Research in Economics, 71(2), 306-336. doi:10.1016/j.rie.2016.05.005.

Granger, C.W.J. (1969) Investigating causal relations by econometric models and crossspectral methods. Econometrica, 37(3), 424-438.

Grossmann, A., Love, I., \& Orlov, A. G. (2014). The dynamics of exchange rate volatility: A panel VAR approach. Journal of International Financial Markets, Institutions and Money, 33, 1-27. doi:10.1016/j.intfin. 2014.07.008.

Hasyim, S., Zulhilmi, M., \& Amri, K. (2019). Is there a causality relationship between law enforcement, crime rates, and economic growth? An empirical evidence from western Indonesia, Regional Science Inquiry 11 (3), 95-109.

Ikhsan, Fitri, C. D., Maulana, H., \& Amri, K. (2020). Effect of inflation on total deposits and financing of sharia commercial banks: A monthly data evidence from Indonesia, Regional Science Inquiry 12 (1), 103-114.

Im, K.S., Pesaran, M.H., \& Shin, Y. (2003). Testing for unit roots in heterogeneous panels. Journal of Econometrics, 115(1), 53-74.

Indonesian Bureau of Statistics. (2019). Statistik Indonesia, BPS, Jakarta.

Inglehart, R., Norris, P., \& Welzel, C. (2002). Gender equality and democracy. Comparative Sociology, 1(3), 321-345. doi:10.1163/156913302100418628.

Jiang, H., \& Liu, C. (2014). A panel vector error correction approach to forecasting demand in regional construction markets. Construction Management and Economics, 32(12), 1205-1221. doi:10.1080/01446193.2014.977800.

Joakim, W. (2006). Some cautions on the use of the LLC panel unit root test, Research Memorandum 055, Maastricht University, Maastricht Research School of Economics of Technology and Organization (METEOR).

Jones, G. A., \& Chant, S. (2009). Globalising initiatives for gender equality and poverty reduction: Exploring "failure" with reference to education and work among urban youth in The Gambia and Ghana. Geoforum, 40(2), 184-196. doi:10.1016/j.geoforum.2008.07.008.

Kao, C. (1999). Spurious regression and residual-based tests for cointegration in panel data. Journal of Econometrics, 90(1), 1-44. 
Klasen, S., \& Schuler, D. (2009). Reforming the gender-related development index (GDI) and the gender empowerment measure (GEM): Some Specific Proposals," Ibero America Institute for Econ. Research (IAI) Discussion Papers 186, Ibero America Institute for Economic Research.

Knutsen, C. H. (2015). Reinvestigating the reciprocal relationship between democracy and income inequality, Review of Economics and Institutions, 6(2), 1-37.

Kumar Mandal, S., \& Madheswaran, S. (2010). Causality between energy consumption and output growth in the Indian cement industry: An application of the panel vector error correction model (VECM). Energy Policy, 38(11), 6560-6565. doi:10.1016/j.enpol.2010.07.042.

Lindberg, S. I. (2004). Women's empowerment and democratization: The effects of electoral systems, participation, and experience in Africa. Studies in Comparative International Development, 39(1), 28-53. doi:10.1007/bf02686314.

Liu, Q.-Q., Yu, M., \& Wang, X.-L. (2015). Poverty reduction within the framework of SDGs and Post-2015 Development Agenda. Advances in Climate Change Research, 6(1), 6773. doi:10.1016/j.accre.2015.09.004.

Maddala, G. S., \& Wu, S. (1999). A comparative study of unit root tests with panel data and a new simple test. Oxford Bulletin of Economics and Statistics, 61(1), 631-652. doi:10.1111/1468-0084.0610s1631.

Mervis, Z., Eve, Z., Florence, M., \& Caroline, M. (2013). The relationship between democracy and women participation in politics, Journal of Public Administration and Governance, 3(1), 168-176.

Murthy, V., \& Okunade, A. (2018). Is the health care price inflation in US urban areas stationary? Evidence from panel unit root tests, Journal of Economics, Finance and Administrative Science, 23 (44), 77-94. https://doi.org/10.1108/JEFAS-02-2017-0043.

Nadim, S. J., \& Nurlukman, A. D. (2017).The impact of women empowerment on poverty reduction in rural area of Bangladesh: Focusing on village development, Journal of Government and Civil Society, 1(2), 135-157.

Nazamuddin, B. S., \& Amri, K. (2020). Does goods and services spendings reduce income inequality? A panel data evidence from Indonesia, Regional Science Inquiry 12 (1), 87102.

Oke, L. (2015). Democracy, women's political participation and the policy environment in Nigeria, Developing Country Studies, 5(10), 1-9.

Pedroni, P. (1999). Critical values for cointegration tests in heterogeneous panels with multiple regressors. Oxford Bulletin of Economics and Statistics, 61(1), 653-670.

Qureshi, M. G., \& Ahmed, E. (2012). The Inter-linkages between democracy and per capita GDP growth: A cross country analysis, PIDE Working Papers No. 85.

Rai, S. M. (1994). Gender and democratization: Or what does democracy mean for women in the Third World? Democratization, 1(1), 209-228. doi:10.1080/13510349408403388.

Raj, A. (2017). Gender Empowerment Index: a choice of progress or perfection, Comment, 5(9), 849-850. https://doi.org/10.1016/S2214-109X(17)30300-5.

Rizzo, H., Abdel-Latif, A.-H., \& Meyer, K. (2007). The relationship between gender equality and democracy: A comparison of Arab versus Non-Arab muslim societies. Sociology, 41(6), 1151-1170. doi:10.1177/0038038507082320.

Schuler, D. (2006). The uses and misuses of the gender-related development index and gender empowerment measure: A review of the literature. Journal of Human Development, 7(2), 161-181. doi:10.1080/14649880600768496.

Shin, K-Y. (2010). The effect of labor force participation by women on family income inequality in Korea, Japan, and Taiwan, Korean Social Science Journal, 27(1), 27-55. 
Sudo, N. (2017). The effects of women's labor force participation: An explanation of changes in household income inequality. Social Forces, 95(4), 1427-1450. doi:10.1093/sf/sox011.

Tremblay, M. (2007). Democracy, representation, and women: A comparative analysis. Democratization, 14(4), 533-553. doi:10.1080/13510340701398261.

Tyer-Viola, L. A., \& Cesario, S. K. (2010). Addressing poverty, education, and gender equality to improve the health of women worldwide. Journal of Obstetric, Gynecologic \& Neonatal Nursing, 39(5), 580-589. doi:10.1111/j.15526909.2010. 01165.x.

Wietzke, F.-B. (2019). Poverty reduction and democratization - new cross-country evidence. Democratization, 1-24. doi:10.1080/13510347.2019.1575369.

Wyndow, P., Li, J., \& Mattes, E. (2013). Female empowerment as a core driver of democratic development: A dynamic panel model from 1980 to 2005. World Development, 52, 34 54. doi:10.1016/j.worlddev.2013.06.004.

Yasar, M., Nelson, C. H., \& Rejesus, R. M. (2006). The dynamics of exports and productivity at the plant level: A panel data error correction model (ECM) approach. Contributions to Economic Analysis, 279-305. doi:10.1016/s0573-8555(06)74011-1. 